\title{
Investigation of factors influencing oxygen content in Halobacterium salinarum growth medium for improved bacteriorhodopsin production
}

\author{
Shadi Rajab ${ }^{1} \cdot$ Valiollah Babaeipour $^{2} \cdot$ Sirwan Khanchezar $^{3} \cdot$ Ghasem Amoabediny $^{4} \cdot$ Fatemeh Yazdian $^{1}$. \\ Mohammad Reza Mofid ${ }^{5}$
}

Received: 31 October 2018 / Accepted: 4 June 2019 / Published online: 11 June 2019

(c) The Author(s) 2019

\begin{abstract}
Improving production of bacteriorhodopsin in the culture medium of Halobacterium salinarum confronts indeterminacy related to culture conditions. Several studies have revealed that high oxygen content increases the growth of Halobacterium salinarum whereas it down-regulates the expression of genes responsible for bacteriorhodopsin production. The focus of this study was to clarify this contradictory role of oxygen in bacteriorhodopsin production and to indirectly regulate the oxygen content of the culture medium at a level that would increase the final concentration of bacteriorhodopsin. Oxygen consumption evaluation showed tha in a typical growth of Halobacterium salinarum at aerobic condition, the decrease in oxygen demand was concurrent with a sharp increase in bacteriorhodopsin production. Further investigation on culture conditions revealed that agitation rate and filling volume had a linear correlation with the cell growth and bacteriorhodopsin production by each cell, however, a two-factor interaction model described the relationship between the culture condition and overall bacteriorhodopsin concentration. It was concluded that although each cell of Halobacterium salinarum produced high amount of bacteriorhodopsin at low turbulence condition, the low yield of biomass production at this condition caused a low overall bacteriorhodopsin concentration. The highest overall bacteriorhodopsin concentration was obtained from high turbulence condition, in which cell numbers were high enough to compensate for low production of bacteriorhodopsin by each cell.
\end{abstract}

Keywords Bacteriorhodopsin $\cdot$ Halobacterium salinarum $\cdot$ Optimization $\cdot$ Oxygen transfer rate

\section{Introduction}

Valiollah Babaeipour

vbabaeipour@mut.ac.ir

1 Department of Life Science Engineering, Faculty of New Sciences and Technologies, University of Tehran, Tehran, Iran

2 Faculty of Chemistry and Chemical engineering, Malek Ashtar University of Technology, Tehran, Iran

3 Department of Biotechnology, Chemical Engineering Faculty, Tarbiat Modares University, Tehran, Iran

4 Research Center for New Technologies in Life Science Engineering, University of Tehran, Tehran, Iran

5 Department of Biochemistry, School of Pharmacy, Isfahan University of Medical Sciences, Isfahan, Iran
Switching of metabolic programs is a common way for microorganisms to adapt and survive from environmental changes, e.g., changing the energy-producing pathway in cyanobacteria in response to light-dark cycle [1]. Halobacterium salinarum (H. salinarum) is a bioenergetically flexible organism which can obtain energy from respiration, retinal-based photosynthesis and fermentation under various environmental conditions [2]. This archaeon lives in highly saline environments where osmotic pressure and temperature may be high and oxygen levels might become low [3, 4]. In such situations, aerobic growth is ceased after a while, therefore, fermentation (if there is sufficient amount of arginine in surroundings) and retinal-based photosynthesis would be the main sources of energy supply for this archaeon in its natural habitat [4]. Retinal-based photosynthesis in H. salinarum is performed by bacteriorhodopsin (BR), a retinal-based, non-chlorophyll protein with a proton-pumping function 
which is activated by absorption of green light. This protein is located in the purple membrane of $H$. salinarum and its production increases under anaerobic conditions when the organism needs photosynthesis to provide energy [2, 5-7]. By absorbing light photons, BR undergoes some conformational changes which leads to proton transfer outward from the cell $[8,9]$. This proton pumping generates an electrochemical gradient across the cell membrane that is used by ATP synthase to produce ATP [7].

Over the last decades, there has been a growing interest in BR and its photochemical/physical characteristic [10]. BR has recently got a lot of actual and potential applications in its native and mutated form [10]. This protein has been used in variety of fields from biology, medicine, and medical instruments (e.g., in protein structure studies, drug screening, treatment of eye disorders and contact lenses) to information technology and electronics (e.g., in optical data storage, holographic storage, security ink and biosensor transducers) [10-13]. Several researchers have focused on enhancing BR production by $H$. salinarum with optimization of medium composition and using some culture strategies (e.g., batch or fed-batch operations), however, fewer of them evaluated culture conditions (e.g., aeration, and agitation rate) [14-16]. Unfortunately, favorable conditions for induction of the bop regulon (including the genes responsible for BR production, i.e., brp, bop and bat genes) is unfavorable for $H$. salinarum growth $[17,18]$. This archaeon grows in aerobic condition up to five times faster than photosynthesis condition (low oxygen concentration in presence of light) [2]. However, the bop regulon induced in photosynthesis condition several times higher than aerobic condition [17]. Since oxygen affects the bop regulon expression and $\mathrm{H}$. salinarum growth differently, regulation of oxygen concentration in the culture medium plays an important role in BR production. The temperature, agitation rate, and the filling volume are some factors which modulate oxygen concentration in a liquid medium. In this study, to increase BR concentration, these oxygen-regulating factors were investigated and optimized.

\section{Materials and methods}

\section{Materials}

All the materials were obtained from the Merck Company (Germany) except that Hy-case was purchased from the Fluka and $\mathrm{MnSO}_{4} \cdot \mathrm{H}_{2} \mathrm{O}$ and DNase $1(\mathrm{DN} 25)$ were purchased from the Sigma-Aldrich co. (Germany).

\section{Microorganism and media}

Halobacterium salinarum R1 (collection number: DSM 671) was purchased from the German Culture Collection (DSMZ, Braunschweig, Germany).

A medium containing $10 \mathrm{gl}^{-1}$ yeast extract; $0.5 \mathrm{gl}^{-1} \mathrm{Hy}$ case; $0.2 \mathrm{gl}^{-1} \mathrm{Na}_{3}$-citrate. $2 \mathrm{H}_{2} \mathrm{O} ; 0.5 \mathrm{gl}^{-1}$ meat extract; $0.5 \mathrm{gl}^{-1}$ glycerol; $20 \mathrm{gl}^{-1} \mathrm{MgSO}_{4} \cdot 7 \mathrm{H}_{2} \mathrm{O} ; 2 \mathrm{gl}^{-1} \mathrm{KCl}$; $0.05 \mathrm{gl}^{-1} \mathrm{FeSO}_{4} \cdot 7 \mathrm{H}_{2} \mathrm{O} ; 0.0002 \mathrm{gl}^{-1} \mathrm{MnSO}_{4} \cdot \mathrm{H}_{2} \mathrm{O}$ and $250 \mathrm{gl}^{-1} \mathrm{NaCl}$ was used as the liquid culture medium in all the experiments. Minerals were autoclaved separately and mixed with other medium components at room temperature to avoid precipitation, then its $\mathrm{pH}$ adjusted to $7.3 \pm 0.1$ aseptically using $1 \mathrm{M} \mathrm{NaOH}$.

\section{Growth kinetic, BR measurement and BR productivity}

For monitoring cell growth, the number of cells was counted using a Neubauer counting chamber. Growth rate in each time interval was calculated from the following equation.

Growth rate $=\frac{\operatorname{Ln}\left(N_{2}\right)-\operatorname{Ln}\left(N_{1}\right)}{T_{2}-T_{1}}$

where $N_{2}$ is the number of cells at the end of the time interval, $N_{1}$ is the number of cells at the beginning of the time interval, and $T_{2}-T_{1}$ is the time interval duration (h).

The concentration of BR in the medium was calculated through the following equation, as previously described [15]

$\operatorname{BR}\left(\mathrm{gl}^{-1}\right)=26,000 \times\left(A_{568}^{0}-A_{568}^{24}\right) / 63,000$

where 26,000 is the molecular weight of $\mathrm{BR}, 63,000$ is its molar extinction coefficient, $A_{568}{ }^{0}$ and $A_{568}{ }^{24}$ are the absorbance of the lysate at $568 \mathrm{~nm}$ in darkness and after exposure to the light for $24 \mathrm{~h}$ (using $50 \mathrm{~W}$ fluorescent lamps, 20,000 lx) respectively.

The overall BR productivity $\left(\mathrm{mg} \mathrm{l}^{-1} \mathrm{~h}^{-1}\right)$ was calculated through dividing the differences of BR concentration $\left(\mathrm{mg}^{-1}\right)$ in each time interval by the duration of the time interval (h).

Amount of BR (pg) located on the surface of each cell in each time (or the ratio of $\mathrm{BR} /$ cells) was determined by dividing $\mathrm{BR}$ concentration ( $\mathrm{pg}^{-1}$ ) by the number of cells $\left(1^{-1}\right)$ in each time.

The BR productivity of each cell $\left(\mathrm{pg} \mathrm{h}^{-1}\right)$ was calculated from dividing the differences of $\mathrm{BR} / \mathrm{cells}$ ratio $(\mathrm{pg})$ in each time interval by the duration of the time interval $(\mathrm{h})$.

All the measurements were carried out in triplicate and the means were reported as the results. 


\section{Oxygen transfer rate and oxygen consumption evaluation}

To assess the oxygen transfer rate (OTR) and oxygen consumption during growth of $H$. salinarum in flasks, a Milli bioreactor (constructed in the University of Tehran, at the Research Center for New Technologies in Life Science Engineering ${ }^{1}$ ) equipped with a respiration activity monitoring system (RAMOS), was used. The vessels of the Milli bioreactor were four 250-ml Erlenmeyer-like flasks, each one with three inlets/outlets (two of them for gas input/output and one of them for inoculation) and a cap equipped with an oxygen sensor. The basis of the RAMOS system was completely described by Anderlei et al. [19, 20]. Briefly, a two-phase measuring cycle continuously repeated. At the first phase (rinsing phase), inlet and outlet of the vessels (covered with sterile filters) were opened and air was flushed through the flasks (at the head space) at $1 \mathrm{VVM}$ flow rate for $20 \mathrm{~min}$. In this phase, the gas composition of the head space (which was resulted from the respiration and metabolism of the surveyed microorganism) was replaced with the fresh air. In the second phase (measuring phase), the inlet and outlet of the vessels were closed and oxygen content of the head space was measured for $160 \mathrm{~min}$. The OTR was computed from the reduction of oxygen partial pressure (resulted from the respiration of the surveyed microorganism) in the headspace of the flasks $[20,21]$. The area under the OTR curve could determine oxygen consumption $(\mathrm{mM})$ by cells [20]. The rate of oxygen consumption $\left(\mathrm{mM} \mathrm{h}^{-1}\right)$ was calculated through dividing the amount of oxygen consumption ( $\mathrm{mM}$ ) in each time interval by the duration of the time interval (h).

For oxygen transfer rate test, culture medium was inoculated with $\mathrm{H}$. salinarum and poured into the sterile vessels. Filling volume, agitation rate, and temperature were $10 \mathrm{ml}$ in 250-ml vessels, $200 \mathrm{rpm}$, and $37^{\circ} \mathrm{C}$, respectively (aerobic condition). This experiment was performed in presence of light (800-1200 lx) to induce BR production [17]. Six nonmonitored shake flasks were running in parallel under the same conditions and used for sampling [22, 20].

\section{Experimental design and statistical data analysis}

In this study, operational parameters including agitation rate, filling volume (which are both effective factors on turbulence of the culture medium), and the temperature (a determining factor for oxygen solubility) were investigated and optimized in shake flasks to increase the production of BR.

Effect of the temperature on the production of BR was examined at three levels of 37,42 , and $47^{\circ} \mathrm{C}$ by one factor at a time method (OFAT). In OFAT experiments agitation

\footnotetext{
${ }^{1}$ https://lse.ut.ac.ir/.
}

Table 1 Experiments designed by RSM for investigation of culture conditions, coded levels and real values (in parentheses) were mentioned

\begin{tabular}{lccl}
\hline $\begin{array}{l}\text { Experiments } \\
\text { number }\end{array}$ & Agitation rate & Culture volume & $\begin{array}{l}\text { Turbu- } \\
\text { lence } \\
\text { condition }\end{array}$ \\
\hline 1 & $1(200 \mathrm{rpm})$ & $-1(100 \mathrm{ml})$ & High \\
2 & $0(140 \mathrm{rpm})$ & $0(225 \mathrm{ml})$ & Average \\
3 & $-1(80 \mathrm{rpm})$ & $-1(100 \mathrm{ml})$ & Average \\
4 & $1(200 \mathrm{rpm})$ & $1(350 \mathrm{ml})$ & High \\
5 & $0(140 \mathrm{rpm})$ & $-1(100 \mathrm{ml})$ & Average \\
6 & $0(140 \mathrm{rpm})$ & $1(350 \mathrm{ml})$ & Low \\
7 & $-1(80 \mathrm{rpm})$ & $1(350 \mathrm{ml})$ & Low \\
8 & $0(140 \mathrm{rpm})$ & $0(225 \mathrm{ml})$ & Average \\
9 & $-1(80 \mathrm{rpm})$ & $0(225 \mathrm{ml})$ & Low \\
10 & $1(200 \mathrm{rpm})$ & $0(225 \mathrm{ml})$ & High \\
\hline
\end{tabular}

rate, filling volume, and light intensity were $200 \mathrm{rpm}, 200 \mathrm{ml}$ medium in 500-ml Erlenmeyer flasks and 5000 lx, respectively. The SPSS 22.0 statistical software package (SPSS, Inc., USA) was used for data analysis by one-way ANOVA and post hoc comparisons (Duncan test) at the significance level of 0.05. Each experiment was repeated for three times and the average value of BR concentration was considered as the final value.

The effects of agitation rate and filling volume (turbulence condition) on cell growth and BR production were evaluated by response surface methodology (RSM; see Table 1). Agitation rates were coded as -1 (low, $80 \mathrm{rpm}$ ), 0 (average, $140 \mathrm{rpm}$ ), and + 1 (high, $200 \mathrm{rpm}$ ). Filling volumes were coded as -1 (low, $100 \mathrm{ml}$ ), 0 (average, $225 \mathrm{ml}$ ), and +1 (high, $350 \mathrm{ml}$ ). The combination of (agitation rate: filling volume $)+1:-1,+1: 0$, and $+1:+1$ were classified as high turbulence condition; $0:-1,0: 0$, and $-1:-1$ considered as average turbulence condition; and $0:+1,-1:+1$ and $-1: 0$ assumed as low turbulence condition. All these experiments were carried out at $42{ }^{\circ} \mathrm{C}$ and $5000 \mathrm{~lx}$ light intensity. The design expert software (version 7) was used for experimental design and data analysis.

\section{Results and discussion}

\section{Correlation between cell growth, BR production and oxygen consumption}

To assess the relation between cell growth, BR production, and the oxygen consumption, these parameters were measured during cell culture of $\mathrm{H}$. salinarum in the Milli bioreactor at aerobic condition. As it was displayed in Fig. 1, overall BR concentration (Fig. 1a) and BR/cells ratio (Fig. 1c) increased gradually during the cell growth. Since BR was 

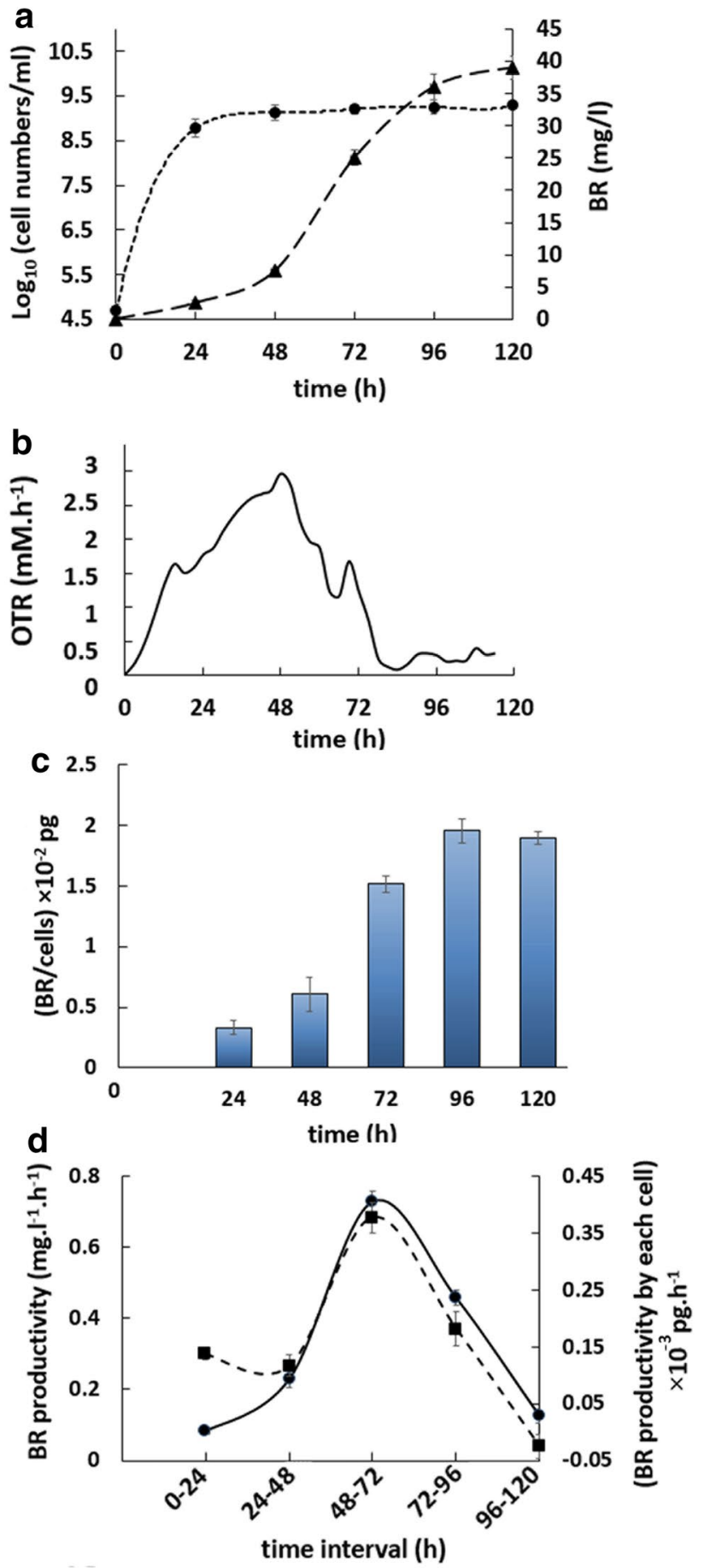

Fig. 1 Overall bacteriorhodopsin concentration (triangle) and cell growth of Halobacterium salinarum in logarithmic scale (circle) measured in parallel experiments with the Milli bioreactor (a); the evolution of oxygen transfer rate in culture medium of Halobacterium salinarum measured by the Milli bioreactor at $37{ }^{\circ} \mathrm{C}, 200 \mathrm{rpm}$ agitation rate, and $10 \mathrm{ml}$ filling volume in a $250-\mathrm{ml}$ vessel (b); bacteriorhodopsin productivity during growth of Halobacterium salinarum (c); the amount of bacteriorhodopsin on each cell surface (BR/cells) over the time (d) produced continuously (albeit sometimes at a low level), its amount on the cells' surfaces or in the culture medium increased by the time. While BR productivity fluctuate significantly at different time intervals. At the first $24 \mathrm{~h}$ of the experiment, the cells grew exponentially (Fig. 1a). In this time period, due to high growth rate $\left(0.39 \mathrm{~h}^{-1}\right.$; Table 2) and high respiration activity, the oxygen demand increased and, therefore, the OTR increased from about 0.0005 to $1.7 \mathrm{mM} \mathrm{h}^{-1}$ (Fig. 1b). Meanwhile, BR productivity (Fig. 1d) was at a very low level. At the second 24-h time interval, the growth rate decreased drastically (up to one tenth of its maximum value, from 0.39 to $0.03 \mathrm{~h}^{-1)}$; Table 2) until the early stationary phase was achieved (Fig. 1a). Surprisingly, oxygen demand continued to increase until the OTR reached its maximum value $\left(\mathrm{OTR}_{\max }=3 \mathrm{mM} \mathrm{h}^{-1}\right)$ at $t=48 \mathrm{~h}$ (Fig. 1b). Such a higher oxygen consumption (see Table 2 and Fig. 1b) and very lower cell growth at this time interval compared to the first 24-h interval suggested that $\mathrm{H}$. salinarum may use a large portion of respiration-derived energy for other activities than cell growth. This result was somewhat in accordance with Gonzalez et al. [2] who reported that $H$. salinarum utilized a large portion of substrates (and thus energy) to produce by-products rather than biomass. At this time, overall BR productivity (Fig. 1d) enhanced slightly (due to probably slight increase in cell counts) while BR productivity of each cell was almost constant (or a little descending). After h 48, cells remained in stationary phase of growth (low growth rate of $0.01 \mathrm{~h}^{-1}$; Table 2), simultaneously oxygen demand started decreasing (Fig. 1b). It seemed that the decrease in oxygen demand of cells after $48 \mathrm{~h}$ of growth was likely due to lack of essential substrates (probably lack of carbon source or substrates for oxidative phosphorylation) [20]. Cells probably shifted their main energy-producing pathway from respiration/fermentation to retinal-based photosynthesis in response to likely essential substrates depletion. Since BR is prerequisite for retinalbased photosynthesis, shifting to photosynthesis could be the reasonable explanation for sharp increase in BR productivity of each cell (and also overall BR productivity) after $48 \mathrm{~h}$ of growth (Fig. 1d). According to the schematic diagram interpretation suggested by Anderlei et al. [20], no oxygen limitation was observed for $H$. salinarum growth in the Milli bioreactor. After h 72, although OTR and growth rate continued to decrease, BR productivity of each cell plunged from its record high $\left(0.00037 \mathrm{pg} \mathrm{h}^{-1}\right)$ to about 0.00018 and $0.0000 \mathrm{pg} \mathrm{h}^{-1}$ at $t=96$ and $t=120$ respectively. A same pattern was observed for overall BR productivity. Based on above-mentioned points, BR productivity was not directly dependent on the value of the growth rate or oxygen consumption, since high or low growth rate or oxygen consumption did not always stimulate cells to alter the rate of BR production. However, BR productivity could be dependent on the growth phase, since it peaked at mid stationary phase 
Table 2 Growth rate, oxygen consumption, and oxygen consumption rate, in $24-\mathrm{h}$ time intervals during growth of Halobacterium salinarum in the Milli bioreactor

\begin{tabular}{lllll}
\hline Time interval $(\mathrm{h})$ & Growth rate $\left(\mathrm{h}^{-1}\right)$ & $\begin{array}{l}\text { Oxygen } \\
\text { consumption } \\
(\mathrm{mM})\end{array}$ & $\begin{array}{l}\text { Oxygen consump- } \\
\text { tion rate }(\mathrm{mM} / \mathrm{h})\end{array}$ & $\begin{array}{l}\text { Rate of oxygen consumption } \\
\text { by each cell }\left(\times 10^{-3} \mathrm{pm} / \mathrm{h}\right)\end{array}$ \\
\hline $0-24$ & $0.39 \pm 0.01$ & $27.33 \pm 2.52$ & $1.14 \pm 0.10$ & $1.91 \pm 0.31$ \\
$24-48$ & $0.03 \pm 0.01$ & $66.00 \pm 4.58$ & $2.75 \pm 0.19$ & $2.23 \pm 0.49$ \\
$48-72$ & $0.01 \pm 0.01$ & $45.00 \pm 3.61$ & $1.88 \pm 0.15$ & $1.14 \pm 0.06$ \\
$72-96$ & $0.00 \pm 0.00$ & $9.67 \pm 1.53$ & $0.40 \pm 0.06$ & $0.22 \pm 0.03$ \\
$96-120$ & $0.00 \pm 0.00$ & $0.00 \pm 0.00$ & $0.00 \pm 0.00$ & $0.00 \pm 0.00$ \\
\hline
\end{tabular}

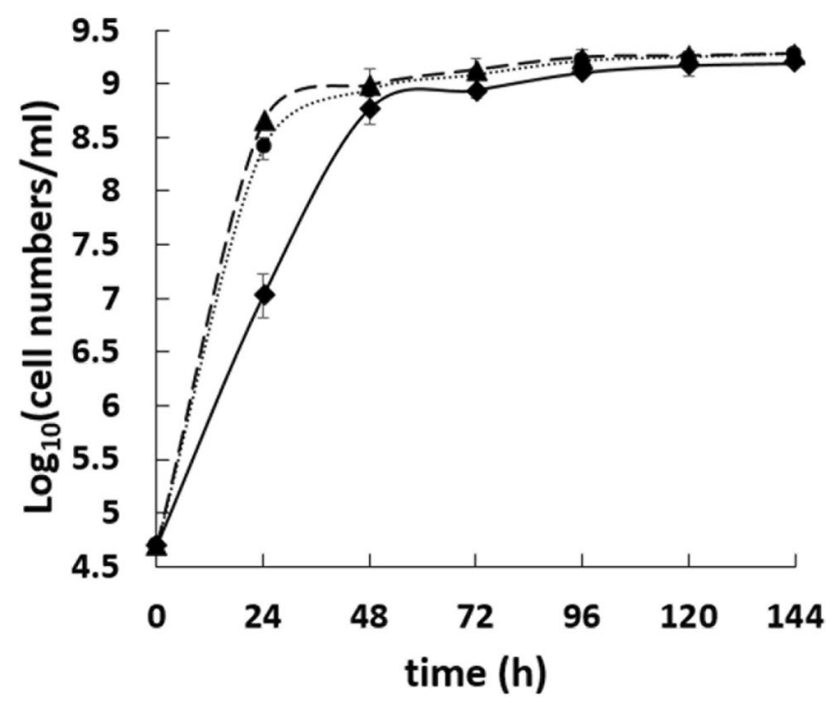

Fig. 2 Growth curve of Halobacterium salinarum in logarithmic scale at three temperatures of $37{ }^{\circ} \mathrm{C}$ (diamond), $42{ }^{\circ} \mathrm{C}$ (circle) and $47{ }^{\circ} \mathrm{C}$ (triangle) at $200 \mathrm{rpm}$ agitation rate, $200 \mathrm{ml}$ filling volume and 5000 lx light intensity in shake flasks

of growth, when essential substrates probably depleted and oxygen consumption (demand) plunged from its record high.

In sum, assessment of oxygen consumption by $\mathrm{H}$. salinarum at aerobic condition showed that BR production may increase drastically when respiration could not be continued due to probably essential substrates depletion. Therefore, inhibiting/reducing respiration by limiting oxygen accessibility could be another option for BR production induction. So, in this study, temperature and turbulence condition, which could affect dissolve oxygen concentration in the medium, were investigated and improved.

\section{Temperature optimization}

Based on previous studies, optimal growth temperature of $H$. salinarum is between $49-50{ }^{\circ} \mathrm{C}$ [23] and such high temperatures decrease oxygen solubility [24] which can induce BR production. Growth of $H$. salinarum at three temperatures of 37,42 and $47^{\circ} \mathrm{C}$ was depicted in Fig. 2. Results showed that cells grew faster at 42 and $47^{\circ} \mathrm{Cthan} 37^{\circ} \mathrm{C}$, also final

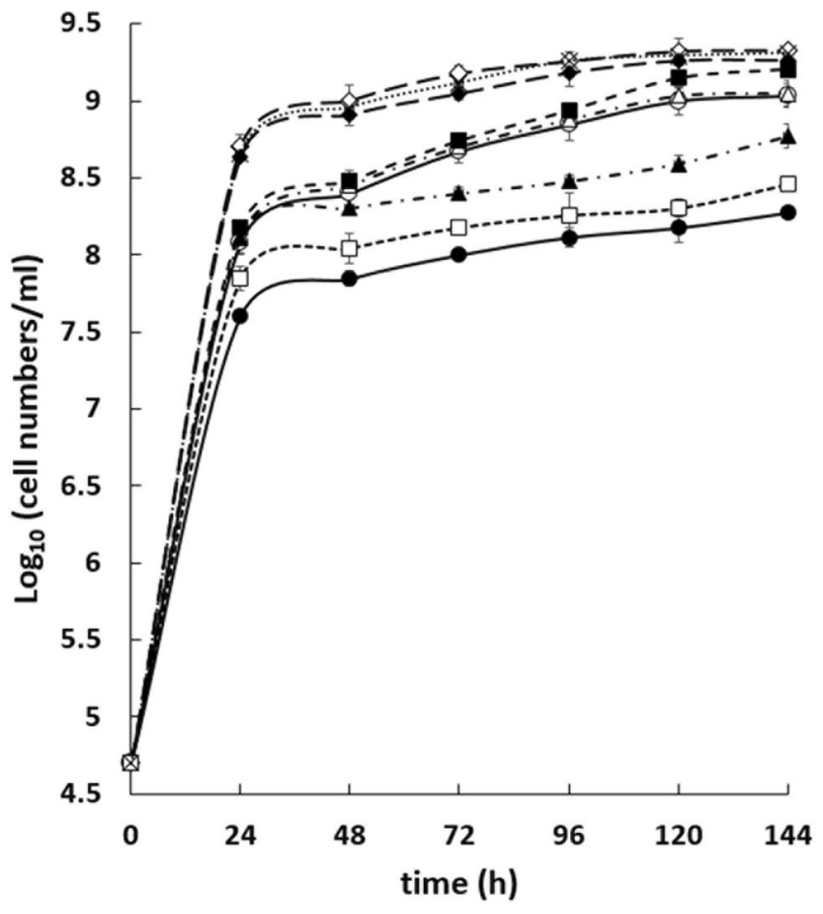

Fig. 3 Growth curve of Halobacterium salinarum in logarithmic scale in various culture conditions designed by response surface methodology (see Table 1), experiments 1, 2 and 8, 3, 4, 5, 6, 7, 8, 9, and 10 were illustrated with closed diamond, closed circle, closed triangle, open diamond, open square, open triangle, open circle, closed square, and the cross respectively

BR concentration at $42{ }^{\circ} \mathrm{C}\left(50.2 \pm 0.8 \mathrm{mg} \mathrm{l}^{-1}\right)$ was more than that of at $37{ }^{\circ} \mathrm{C}\left(46 \pm 0.5 \mathrm{mg} l^{-1} ; p<0.05\right)$ and $47^{\circ} \mathrm{C}$ (48.5 $\left.\pm 1 \mathrm{mg} \mathrm{l}^{-1} ; p<0.05\right)$. So, among these three temperatures, $42{ }^{\circ} \mathrm{C}$ selected as the optimum temperature.

\section{Turbulence condition (agitation rate and filling volume) improvement}

Figure 3 showed $H$. salinarum growth in logarithmic scale under different turbulence conditions (based on experiments mentioned in Table 1). In all the experiments, like the experiment conducted in the Milli bioreactor, the first $24 \mathrm{~h}$ was the exponential phase of growth. After that 
Fig. 4 Bacteriorhodopsin concentration (column) and the ratio of BR/cells (square) in constant filling volumes (a for $100 \mathrm{ml}$, b for $225 \mathrm{ml}$ and $\mathbf{c}$ for $350 \mathrm{ml}$ volumes) with agitation rate as the variable, and in constant agitation rates $\mathbf{d}$ for $200 \mathrm{rpm}$, $\mathbf{e}$ for $140 \mathrm{rpm}$ and $\mathbf{f}$ for $80 \mathrm{rpm}$ agitation rates) with filling volume as the variable; black, hachured, and white columns indicated high, average, and low turbulence conditions respectively (see Table 1)

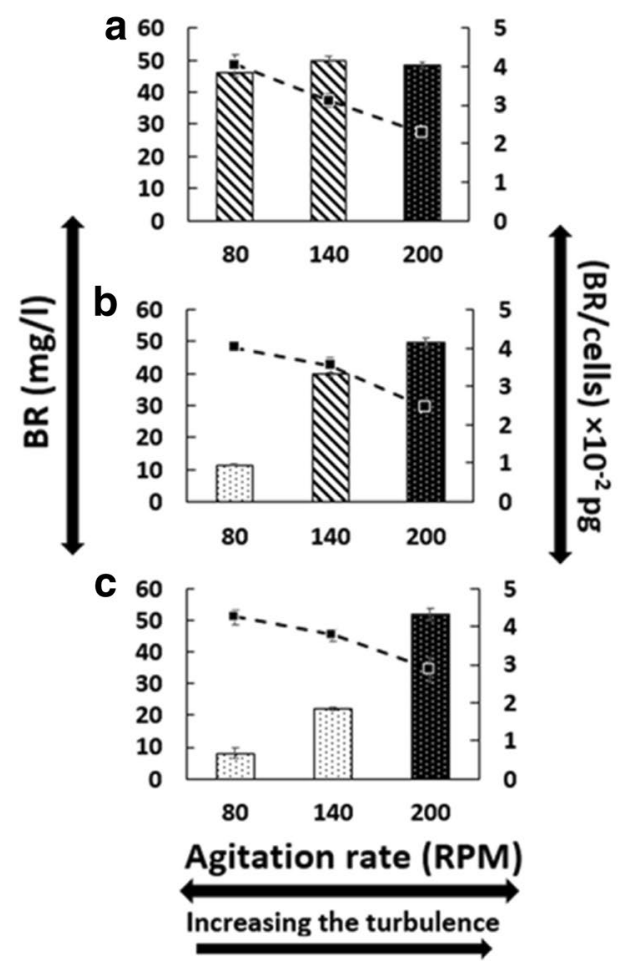

the growth rate decreased and cells entered the stationary phase. According to different turbulence conditions and thus different oxygen accessibility of the cells, exponential growth ceased with lower biomass yield in lower turbulence condition compared to higher turbulence condition. Based on Ming and Zhenhao prediction [25] oxygen solubility in a $4 \mathrm{M} \mathrm{NaCl}$ solution (like H. salinarum culture medium) at $39-45{ }^{\circ} \mathrm{C}$ is about $0.06-0.07 \mathrm{mmol} /$ $\mathrm{Kg}$, which is 4.1 times lower than its solubility in the water $(\mathrm{NaCl}=0 \%)$. Therefore, culture medium of $\mathrm{H}$. salinarum made problems for preparing aerobic conditions. It seemed that with this medium composition, only high turbulence conditions could provide sufficient amount of oxygen for aerobic growth. It appeared that this oxygen demand could not be completely met in average and low turbulence conditions and this could be the reason of early cessation in exponential growth and lower cell numbers in average and low turbulence conditions compared to high turbulence condition. At the end of the logarithmic growth phase, cells grown at high turbulence condition (experiments 1,4 and 10 with a $\mu_{\max }$ of about $0.38 \pm 0.01 \mathrm{~h}^{-1}$ ) reached to as high as $8.66 \pm 0.03 \log _{10}$ cell numbers $\mathrm{ml}^{-1}$ (which was not significantly different from the result of the experiment done in the Milli bioreactor) whereas cells at average (experiments 5, 3, 2 and 8 with a $\mu_{\max }$ of about $0.33 \pm 0.01 \mathrm{~h}^{-1}$ ) and low (experiments 6 , 7 and 9 with a $\mu_{\max }$ of about $0.29 \pm 0.02 \mathrm{~h}^{-1}$ ) turbulence conditions reached to $8.12 \pm 0.05$ and $7.85 \pm 0.26 \log _{10}$ cell numbers $\mathrm{ml}^{-1}$ respectively. After that, cells growth continued until the end of the experiment $(t=120 \mathrm{~h})$ with a very low growth rate to reach $9.29 \pm 0.04,9.08 \pm 0.08$, and $8.47 \pm 0.22$ at high, average, and low turbulence conditions respectively. Therefore, as the oxygen accessibility of the culture medium increased due to enhancing turbulence condition, cells grew to a higher density.

Figure 4 depicted the amount BR produced by each cell (ratio of BR/cells) and overall BR concentration at different turbulence conditions. The highest BR production of each cell were of $80 \mathrm{rpm}$ agitation rate (with $0.0405 \pm 0.0017$, $0.0402 \pm 0.0020$, and $0.0425 \pm 0.0010 \mathrm{pg}$ BR produced at, respectively, 100, 225, and $350 \mathrm{ml}$ filling volumes). After that $140 \mathrm{rpm}$ (with $0.0312 \pm 0.0020,0.0350 \pm 0.0005$, and $0.0378 \pm 0.0012 \mathrm{pg} \mathrm{BR}$ produced at, respectively, 100,225 , and $350 \mathrm{ml}$ filling volumes) and $200 \mathrm{rpm}$ (with $0.0228 \pm 0.0022,0.0245 \pm 0.0018$, and $0.0287 \pm 0.0015 \mathrm{pg}$ BR produced at, respectively, 100, 225, and $350 \mathrm{ml}$ filling volumes) agitation rates took the second and third place respectively. With regard to filling volume, each cell produced higher amount of BR at $350 \mathrm{ml}$ filling volume compared with 225 and $100 \mathrm{ml}$. In other words, an incremental trend in $\mathrm{BR} /$ cells ratio was seen when the turbulence of the medium decreased. As the $\mathrm{BR} /$ cells ratio is a representative of the amount of BR on each cell surface, this result means that each cell of $H$. salinarum produces more BR in oxygen limited environments (or by decreasing the turbulence in the medium). This result confirmed the result of Shand et al. [17] where an enhancement in expression of bop gene was seen by decreasing the oxygen content of the medium. 
According to Fig. 4, at the first look, the overall BR concentration showed an increment trend with increasing the turbulence (Fig. 4b-e). However, when the differences between various turbulence conditions were small (Fig. 4a, f) differences between overall BR concentrations at these conditions were very low/almost insignificant. In fact, trend of overall BR concentration could not be precisely predicted in response to turbulence condition, since overall BR concentration was dependent on both the cell numbers and the amount of BR production by each cell, and these two parameters respond oppositely to alteration of the turbulence condition.

\section{Suggested models for the effect of different turbulence condition on cell growth, BR/cells ratio, and overall BR production}

According to analysis of variance linear models could describe the effect of agitation rate and filling volume on cell growth $\left(R^{2}=0.93, p<0.0001\right)$ and $\mathrm{BR}$ production by each cell $\left(\mathrm{BR} /\right.$ cells ratio; $\left.R^{2}=0.95, p<0.0001\right)$, however, a $2 \mathrm{fi}$ model was more appropriate for explaining the effect of agitation rate and filling volume on overall BR concentration $\left(R^{2}\right.$ of $\left.0.93, p<0.001\right)$. These models were shown in the following equations.

Cell numbers $\mathrm{ml}^{-1}=1.19 \times 10^{9}+7.29 \times 10^{8} \mathrm{~A}-3.74 \times 10^{8} B$

$\mathrm{BR}(\mathrm{pg})$ produced by each cell(BR/cells ratio)

$$
=3.4 \times 10^{-3}-7.9 \times 10^{-4} A+2.4 \times 10^{-4} B
$$

Overall BR concentration $\left(\mathrm{mg}^{-1}\right)$ in the medium

$$
=36.44+14.63 A-10.97 B+11.35 A B
$$

where $A$ and $B$ are the coded levels of agitation rate and filling volume respectively.

As it was shown in the above equations, the effects of agitation rate and filling volume on cell growth and BR production by each cell were completely opposite. These opposite effects confirmed contradictory role of oxygen in cell growth and BR production by each cell. However, the effects of agitation rate and filling volume on overall BR concentration were more complicated. The role of agitation rate on overall BR concentration was positive (with the coefficient of +14.63 ). Filling volume with the coefficient of -10.97 , individually had a negative role in overall BR concentration. However, the combined effect of agitation rate and filling volume (depicted in Fig. 5) could affect the final BR concentration with the coefficient of +11.35 . Based on Fig. 5, generally, the combination of (agitation rate: filling volume) $+1:+1,+1: 0,+1:-1,0:-1$, and $-1:-1$ (which all prepare high/average turbulence conditions) resulted in higher BR concentration compared to other tested conditions. Based on this study, the best condition for overall BR

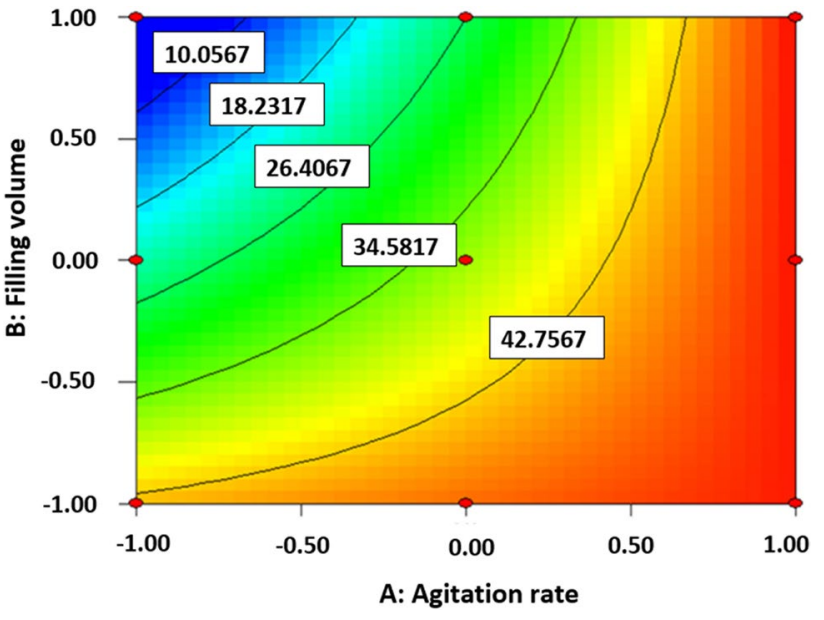

Fig. 5 The combined effect of agitation rate and filling volume on overall bacteriorhodopsin concentration; $x$ - and $y$-axis represent the coded levels $(-1,0,+1)$ of agitation rate and filling volume; moving from blue to red colored areas increases overall BR concentration; numbers in boxes indicate the predicted bacteriorhodopsin concentration in the same colored areas

production were at $200 \mathrm{rpm}$ agitation rate and $350 \mathrm{ml}$ filling volume at which BR concentration was $52 \pm 0.9 \mathrm{mg}^{-1}$.

\section{Conclusion}

Protein production process is dependent on the two parameters: the number of protein producer cells and the intensity of the expression of the genes responsible for production of the intended protein. The capacity of membrane protein production is related to the membrane surface area, which is enhanced by increasing the number of cells, also full exploitation of this capacity depends on maximizing the expression of the intended protein in each cell. Considering these two parameters and balancing them (if maximizing both of them at a same time is not possible) is a key to improve protein production. In BR production process, conditions for enhancement of cell numbers and induction of the expression of bop gene cluster are opposite of each other. However, it was demonstrated in this study that to enhance the overall BR concentration in the culture medium of $\mathrm{H}$. salinarum, increasing cell numbers were more preferred than maximizing BR production of each cell. At low turbulence condition (low oxygen content) high production of BR by each cell could not compensate for the negative effect of low cell numbers, however, at high turbulence conditions (high oxygen content) the high number of cells covered the reducing-effect of low BR production by each cell on the overall BR concentration. Furthermore, at some conditions with average turbulence a balance was established between cell numbers and BR production by each cell which could 
finally increase overall BR concentration to a high level in the culture medium.

Acknowledgements We gratefully acknowledge the research center for new technologies in life science engineering for offering the Milli bioreactor.

Open Access This article is distributed under the terms of the Creative Commons Attribution 4.0 International License (http://creativeco mmons.org/licenses/by/4.0/), which permits unrestricted use, distribution, and reproduction in any medium, provided you give appropriate credit to the original author(s) and the source, provide a link to the Creative Commons license, and indicate if changes were made.

\section{References}

1. Puszynska AM, O'Shea EK (2017) Switching of metabolic programs in response to light availability is an essential function of the cyanobacterial circadian output pathway. eLife 6:e23210

2. Gonzalez O, Gronau S, Pfeiffer F, Mendoza E, Zimmer R, Oesterhelt D (2009) Systems analysis of bioenergetics and growth of the extreme halophile Halobacterium salinarum. PLoS Comput Biol 5(4):e1000332

3. Ma Y, Galinski EA, Grant WD, Oren A, Ventosa A (2010) Halophiles 2010: life in saline environments. Appl Environ Microbiol 76(21):6971-6981

4. Oesterhelt D, Tittor J (1989) Two pumps, one principle: lightdriven ion transport in halobacteria. Trends Biochem Sci 14(2):57-61

5. Lake JA, Clark MW, Henderson E, Fay SP, Oakes M, Scheinman A, Thornber J, Mah R (1985) Eubacteria, halobacteria, and the origin of photosynthesis: the photocytes. Pro Natl Acad Sci USA 82(11):3716-3720

6. Ovchinnikov YA, Abdulaev N, Feigina MY, Kiselev A, Lobanov N (1977) Recent findings in the structure-functional characteristics of bacteriorhodopsin. FEBS lett 84(1):1-4

7. Hartmann R, Sickinger H-D, Oesterhelt D (1980) Anaerobic growth of halobacteria. Proc Natl Acad Sci USA 77(7):3821-3825

8. Oesterhelt D, Stoeckenius W (1973) Functions of a new photoreceptor membrane. Proc Natl Acad Sci USA 70(10):2853-2857

9. Lozier RH, Bogomolni RA, Stoeckenius W (1975) Bacteriorhodopsin: a light-driven proton pump in Halobacterium halobium. Biophys J 15(9):955-962

10. Mahyad B, Janfaza S, Hosseini ES (2015) Bio-nano hybrid materials based on bacteriorhodopsin: potential applications and future strategies. Adv Colloid Interface Sci 225:194-202

11. Abarghooi Kahaki F, Babaeipour V, Rajabi Memari H, Mofid MR (2014) High overexpression and purification of optimized bacterio-opsin from Halobacterium Salinarum R1 in E. coli. Appl Biochem Biotechnol 174:1558-1571
12. Bott RR, Jensen RB, Kelemen BR, Donald EWI, Whited GM (2013) Composition comprising various proteorhodopsins and/ or bacteriorhodopsins and use thereof. US Patent Application No. 13/974,988; 2013

13. Li Y-T, Tian Y, Tian H, Tu T, Gou G-Y, Wang Q, Qiao Y-C, Yang Y, Ren T-L (2018) A review on bacteriorhodopsin-based bioelectronic devices. Sensors 18(5):1368

14. Kalenov SV, Baurina MM, Skladnev DA, Kuznetsov AY (2016) High-effective cultivation of Halobacterium salinarum providing with bacteriorhodopsin production under controlled stress. J Biotechnol 233:211-218

15. Ghasemi MF, Shodjai-Arani A, Moazami N (2008) Optimization of bacteriorhodopsin production by Halobacterium salinarium PTCC 1685. Process Biochem 43(10):1077-1082

16. Lee SY, Chang HN, Um YS, Hong SH (1998) Bacteriorhodopsin production by cell recycle culture of Halobacterium halobium. Biotechnol Lett 20(8):763-765

17. Shand RF, Betlach MC (1991) Expression of the bop gene cluster of Halobacterium halobium is induced by low oxygen tension and by light. J Bacteriol 173(15):4692-4699

18. Shand RF, Betlach MC (1994) bop gene cluster expression in bacteriorhodopsin-overproducing mutants of Halobacterium halobium. J Bacteriol 176(6):1655-1660

19. Anderlei T, Zang W, Papaspyrou M, Büchs J (2004) Online respiration activity measurement (OTR, CTR, RQ) in shake flasks. Biochem Eng J 17(3):187-194

20. Anderlei T, Büchs J (2001) Device for sterile online measurement of the oxygen transfer rate in shaking flasks. Biochem Eng J 7(2): 157-162

21. Seletzky JM, Noack U, Hahn S, Knoll A, Amoabediny G, Büchs J (2007) An experimental comparison of respiration measuring techniques in fermenters and shake flasks: exhaust gas analyzer vs. RAMOS device vs. respirometer. J Ind Microbiol Biotechnol 34(2): 123-130

22. Guez J, Müller C, Danze P, Büchs J, Jacques P (2008) Respiration activity monitoring system (RAMOS), an efficient tool to study the influence of the oxygen transfer rate on the synthesis of lipopeptide by Bacillus subtilis ATCC6633. J Biotechnol 134(1-2):121-126

23. Robinson JL, Pyzyna B, Atrasz RG, Henderson CA, Morrill KL, Burd AM, DeSoucy E, Fogleman RE, Naylor JB, Steele SM (2005) Growth kinetics of extremely halophilic Archaea (family Halobacteriaceae) as revealed by Arrhenius plots. J Bacteriol 187(3):923-929

24. Millero FJ, Huang F (2003) Solubility of oxygen in aqueous solutions of $\mathrm{KCl}, \mathrm{K}_{2} \mathrm{SO}_{4}$, and $\mathrm{CaCl}_{2}$ as a function of concentration and temperature. J Chem Eng Data 48(4):1050-1054

25. Ming G, Zhenhao D (2010) Prediction of oxygen solubility in pure water and brines up to high temperatures and pressures. Geochim Cosmochim Acta 74(19):5631-5640

Publisher's Note Springer Nature remains neutral with regard to jurisdictional claims in published maps and institutional affiliations. 